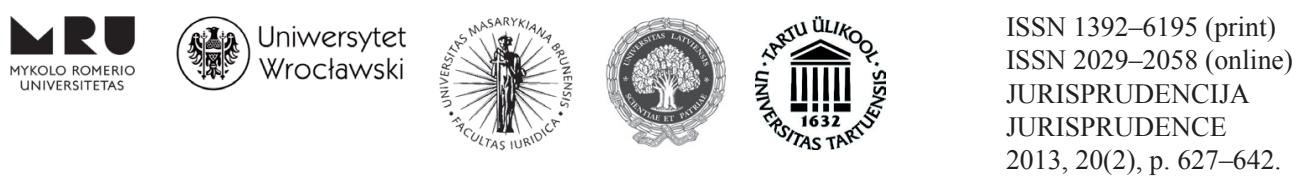

\title{
SOME THOUGHTS CONCERNING THE MAIN GOALS OF COMPETITION LAW
}

\author{
Raimundas Moisejevas \\ Law firm SORAINEN; \\ Mykolas Romeris University,Faculty of Law, Business Law Department \\ Ateities 20, LT-08303 Vilnius, Lithuania \\ Telephone (+370 5) 2714525 \\ E-mail: raimundasm@mruni.eu
}

Ana Novosad

Mykolas Romeris University, Faculty of Law,

Business Law Department

Ateities 20, LT-08303 Vilnius, Lithuania

Telephone (+370 5) 2714525

E-mail: ana_novosad@yahoo.com

Received on 30 May, 2013; accepted on 25 June, 2013

doi:10.13165/JUR-13-20-2-14

\begin{abstract}
The aim of this article is to analyse different goals of the competition law, which are established in European Union and Lithuania. EU Commission and the Court of Justice distinguish a number of goals of the competition law. Most commonly, mentioned goals of competition law are the following: the integration of the Internal Market, the protection of consumers, protection of the competitors, freedom of competition and economic efficiency. Different goals of competition law are analysed in this paper and relationship between them is explained. Special attention is given to the analysis of protection of the consumers as one of the main objectives of competition law. While analysing protection of the consumers in competition law, a difference between the concept of consumer in competition law and consumer protection law is explained. The authors express a number of critical


thoughts towards practice of the EU Commission and the Court of Justice so far, as there is a lack of consistency in evaluation of the protection of consumers' rights in the context of the other objectives of competition law. Relevance of the present article is supported by the several facts such as revision of the competition law goals by the EU Commission and adoption of resolution "Concerning priority of the activities of the Lithuanian Competition Council" by the Lithuanian Competition Council that establishes main principles (priorities) applied while implementing competition policy in Lithuania. Setting out the main goals in Lithuanian competition law may have important practical consequences in the everyday activities of the Lithuanian national competition authority.

Keywords: Goals of the competition law, abuse of dominant position, anticompetitive agreements, integration of the internal market, protection of consumers, effective competition.

\section{Introduction}

While assessing the novelty of this article, it should be mentioned that Lithuanian legal scholars have not published any articles or other studies, which would be clearly devoted to the analysis of the goals of EU or Lithuanian competition law. EU competition law scientists paid more attention to that issue, e.g. I. Lianos ${ }^{1}, \mathrm{R}$. Whish ${ }^{2}$, etc. The authors of this article believe that it is very important to identify main goals of competition law, since in such case the competition authorities and the courts could perform their interpretation and application of competition law in accordance with the main objectives in competition law and thus effectively contribute to their achievement. The importance of the competition law goals has been always acknowledged but the importance of one or another goal has been constantly rethought by the EU Commission and the courts as well as scholars. Finally, the Commission has cleared out its enforcement priorities and published them in the 2009 Communication $^{3}$, however it seems that the position of the EU courts is not consistent. At this point, we should mention that the Lithuanian Competition Council on 2nd July, 2012 adopted the resolution No. 1S-89 "Concerning priority of the activities of the Lithuanian Competition Council". ${ }^{4}$ Respective resolution of the Lithuanian Competition Council establishes main guiding principles for the implementation (though mostly initiation) of competition law enforcement and policy. Therefore, the Lithuanian Competition Council also recognizes importance of clear

1 Lianos, I. Some Reflections on the Question of the Goals of EU Competition Law, Centre for Law, Economics and Society. CLES Working Paper Series. 2013, 3.

2 Whish, R.; Bailey, D. Competition Law. Seventh Edition. London: Oxford University Press, 2012.

3 Communication from the Commission. Guidance on the Commission's Enforcement Priorities in Applying Article 82 of the EC Treaty to Abusive Exclusionary Conduct by Dominant Undertakings. (2009/C 45/02).

4 Lietuvos Respublikos Konkurencijos tarybos nutarimas dèl Lietuvos Respublikos Konkurencijos tarybos veiklos prioriteto. Vilnius. $2012 \mathrm{~m}$. liepos 2 d. Nr. 1S-89. 
establishment of the main goals of the competition law. Such clarification of the main goals may have important practical consequences in the everyday activities of the Lithuanian national competition authority.

Objectives of competition law were also distinguished by the courts and the scholars. Most commonly, mentioned goals of competition law are the following: the integration of the Internal Market, the protection of consumers, protection of the competitors, freedom of competition and economic efficiency. In most cases, the courts and competition authorities recognize that multiple goals of the competition coexist together.

The object of this article is the main goals of the competition law and their application in practice.

The authors of this article analyse the decisions of the Court of Justice, the General Court and the Lithuanian Competition Council and also legal acts adopted in the European Union and Lithuania.

The goal of this article is to clarify different goals in the competition law, which are established in Lithuania and European Union through the use of logical, systematic analysis and comparative and linguistic research methods.

\section{Multiple goals of competition law}

Though a large number of objectives in EU competition law may be distinguished, only most important of them are analysed below.

The integration of the Internal Market is regarded as one of the main aims of EU law in general and competition law particularly. Since provisions on competition law are a part of EU law, they have to be interpreted bearing in mind general purposes of the European Union. The authors of this article tend to agree with R. Wesseling, who claims that initially competition law provisions have been included into the EC treaty, bearing in mind their importance for the market integration. R. Wesseling points out that provisions which related to the competition law have been drafted considering rules established in Articles 28-30 of the EC Treaty. ${ }^{5}$ It should be recalled that Articles 2830 of the EC Treaty (presently Articles 34-36 of the Treaty on the Functioning of the European Union ${ }^{6}$ (TFEU)) are central for the successful integration of the EU market, since these provisions prohibit establishment of any quantitative restrictions (and all measures having equivalent effect) on imports and exports. We may presume that fathers of the EC Treaty intended to prohibit private undertakings from replacing obstacles for the trade between member states, which had to be removed by above mentioned articles. The Court of Justice mentioned on a number of occasions that Article 101 of the Treaty constitutes a fundamental provision, which is essential for the accomplishment of the tasks entrusted to the Community and, in particular, for the functioning of the internal

5 Wesseling, R. The Modernisation of EC Antitrust Law. Oxford: Hart Publishing, 2000, p. 48-49.

6 Treaty on the Functioning of the European Union. Consolidated version [2010] OJ C 83/47. 
market $^{7}$, e.g, in case producer of cars would sign vertical agreement with its distributors that contains provisions equivalent to absolute territorial protection, then the integration of the internal market might be endangered. Another example of the practice, which may have negative effect on the integration of the internal market, might be arrangement of the undertakings to establish certain discriminatory practices in relation to the undertakings coming from different EU member states.

As a practical result of recognition of integration of the internal market as one of the main aims of competition law, agreements of the undertakings concerning absolute territorial protection, restrictions to parallel trade, sharing of the markets or/and customers and also restrictions to exports as a rule are viewed as restrictions of competition by the object. Once it has been established that an agreement has the restriction of competition as its object, there is no need to take account of its specific effects. ${ }^{8}$ In other words, for the purpose of applying Article 101 (1) of the TFEU, no actual anti-competitive effects need to be demonstrated where the agreement has a restriction of competition as its object. ${ }^{9}$ Lianos believes that possible explanation of such a restrictive approach to any conduct that jeopardizes the principle of market integration is its significance as a political objective for the EU, the idea being that a common market will ultimately lead to political unification. ${ }^{10}$

As a rule, it is considered that protection of the consumers is one of the main aims of the competition law. Antitrust laws of the United States quite clearly specify that protection of the consumers is the main objective of competition. On the other hand, protection of the consumers in the European Union is just one of the goals of the competition law (though actually leading ones), which coexists with other aims. Protection of the consumers as an objective of the competition law will be analysed in more detail later.

Achievement of effective competition is also viewed as one of the main aims by the European Commission and by national competition authorities. According to the Report on the objectives of unilateral conduct laws, assessment of dominance/ substantial market power and state-created monopolies prepared by the ICN Unilateral Conduct Working Group (UCWG) thirty-two of thirty-three agencies cited ensuring an effective competitive process, as a goal of their unilateral conduct rules and/or as a means to achieve other goals. ${ }^{11}$ The EU Commission has also clearly stressed in its

7 Case C-453/99 Courage v. Crehan [2001] ECR I-627, para. 20; Case C-126/97 Eco Swiss [1999] ECR I-3055, para. 36.

8 Case C-49/92 P, Anic Partecipazioni, [1991] ECR I-4125, para. 99.

9 Communication from the Commission, Notice, Guidelines on the Application of Article 81 (3) of the Treaty, (2004/C 101/08), para. 20.

10 Lianos, I. Some Reflections on the Question of the Goals of EU Competition Law, Centre for Law, Economics and Society. CLES Working Paper Series. 2013, 3: 14.

11 The Unilateral Conduct Working Group. International Competition Network. Report on the Objectives of Unilateral Conduct Laws, Assesment of Dominance/Substantial Market Power, and State Created Monopolies. 2013, p. 6 [interactive]. [accessed on 21-5-2013]. <http://www. internationalcompetitionnetwork.org/uploads/library/doc353.pdf>. 
2009 Communication ${ }^{12}$ that "the emphasis of the Commission's enforcement activity in relation to exclusionary conduct is on safeguarding the competitive process in the internal market and ensuring that undertakings which hold a dominant position do not exclude their competitors by other means than competing on the merits of the products or services they provide. In doing so the Commission is mindful that what really matters is protecting an effective competitive process and not simply protecting competitors" (emphasis added). Indeed, one of the basic purposes of competition policy is to ensure a process of effective competition in order to achieve efficient allocation of resources. As it is widely acknowledged that the competition is beneficial for consumers, it may also be stated that the final beneficiary of protection of competition process is a consumer and therefore safeguarding competition also ensures protection of consumers.

Freedom to compete as the aim of the competition law has a background in the ordoliberal notion of the competition law developed by the scholars from the German Freiburg University ${ }^{13}$. Ordoliberals believe that competition is necessary in order to ensure economic development and creation of a free market economy. Protection of the freedom to compete may help to weaken economic power of the dominant undertakings and achieve deconcentrated markets. Ordoliberal point of view may be viewed not only as aiming to control entrenched market power, but even as an attempt to preserve political democracy. ${ }^{14}$ Ordoliberal ideas on freedom to compete have influenced jurisprudence of the Court of Justice in abuse of dominance cases. However, the relation between this goal and the goal of protection of effective competition is questionable. In accordance with the abovementioned EU Commission's position, the competition law seeks to protect competition process as such, but not interests of certain competitors (including interest to compete freely).

As mentioned, significance of the protection of the competitors as the aim of the competition law is quite ambiguous. Certain controversies are especially obvious, if we analyse the protection of the competitors in abuse of dominance cases. Recently, the European Commission has intended to make some changes in relation to its policy of the protection of the competitors. Below we will provide some thoughts claiming that protection of the interests of competitors does not always coincide with the protection of the interests of consumers.

Objective of the protection of small and medium-sized enterprises (SMEs) relates to some controversies, quite similarly as the aim of the protection of the competitors does. EU competition law and national laws on competition of the member states aim to protect small and medium sized enterprises. It should be noted that there has been a shift towards this objective in the U.S. It was thought in the U.S. that protection of small or medium enterprises may become protection of such companies from efficient

12 Communication from the Commission. Guidance on the Commission's Enforcement Priorities in Applying Article 82 of the EC Treaty to Abusive Exclusionary Conduct by Dominant Undertakings. (2009/C 45/02), para 6

13 Gormsen. L.L. Article 82 EC: Where Are We Coming From and Where Are We Going to? The Competition Law Review. 2006, 2(2): 9-11.

14 Lianos, I. Some Reflections on the Question of the Goals of EU Competition Law, Centre for Law, Economics and Society. CLES Working Paper Series. 2013, 3: 26. 
merit-based competition. Therefore, this objective was eliminated from the list of the objectives under U.S. antitrust law. ${ }^{15}$

Objectives of competition law also include the following: maximizing efficiency, promoting fairness and equality, facilitating privatization and market liberalization, promoting competitiveness in international markets and these are not exhaustive. However, the main aims of the competition law were described herein above and the further analysis is concentrated on the leading goal - protection of consumers.

\section{The protection of the consumers as one of the main goals}

The necessity to protect the interests of the consumers is directly mentioned in the legal acts referring to anticompetitive agreements, abuse of dominant position and concentrations. Article 101 (3) of the TFEU provides that exemption to the anticompetitive agreement may be granted inter alia, if such an agreement allows consumers to receive a fair share of the resulting benefit. Article 102 in paragraph b) prohibits abuse of a dominant position by limiting production, markets or technical development to the prejudice of consumers. The EC Merger Regulation provides in the Article 2 that the Commission during evaluation of the concentration shall take into account inter alia the interests of the intermediate and ultimate consumers. ${ }^{16}$ Protection of the interest of consumers is also strengthened through Commission's encouragement of consumers to bring claims in case they have suffered damages as a consequence of competition law breaches. Articles 6 and 7 of the Lithuanian Law on Competition ${ }^{17}$ also emphasize the protection of consumer interests.

Officially the Commission claims that enforcement of Article 102 of the TFEU should focus on evaluation whether actions of the dominant undertaking negatively affect market or not and hereby cause damage to the consumers. ${ }^{18}$ It is recognized that Article 102 is designed to ensure welfare of the consumers and effective distribution of the resources and this Article is not aimed for the protection of the competitors by themselves on the market. ${ }^{19}$ The Commission claims in its 2009 Communication - "Guidance on the Commission's Enforcement Priorities in Applying Article 82 of

15 The Unilateral Conduct Working Group. International Competition Network. Report on the Objectives of Unilateral Conduct Laws, Assesment of Dominance/Substantial Market Power, and State Created Monopolies.2013,p. 18 [interactive]. [accessed21-5-2013]. <http://www.internationalcompetitionnetwork. org/uploads/library/doc353.pdf>.

16 Regulation (EC) 139/2004 on the Control of the Concentrations Between Undertakings, OJ 2004, L 24/1.

17 Law on Competition of the Republic of Lithuania. Official Gazette. 1999, No. 30-856. (new edition from 01/05/2012. 2012, Nr. 42-2041).

18 Kroes, N. European Commissioner for Competition Policy. Preliminary Thoughts on Policy Review of Article 82. Speech at the Fordham Corporate Law Institute. New York: 23th September 2005. Antitrust: Consumer Welfare at Heart of Commission Fight Against Abuses by Dominant Undertakings. Brussels: 3rd December 2008, IP/08/1877.

19 Kroes, N. European Commissioner for Competition Policy. Preliminary Thoughts on Policy Review of Article 82. Speech at the Fordham Corporate Law Institute. New York: 23rd September 2005. 
the EC Treaty to Abusive Exclusionary Conduct by Dominant Undertakings", that in applying Article 102 of the TFEU to exclusionary conduct by dominant undertakings, the Commission will focus on those types of conduct that are most harmful to consumers. The Commission believes that consumers benefit from competition through lower prices, better quality and a wider choice of new or improved goods and services. Therefore, the Commission provides that it will direct its enforcement to ensuring that markets function properly and that consumers benefit from the efficiency and productivity. ${ }^{20}$

The Commission sees direct relationship between protection of the consumer welfare and protection of the competition by stating that the dominant undertakings should be prohibited to foreclose their competitors in an anti-competitive way, thus having adverse effect on consumer welfare. ${ }^{21}$ The Commission believes that effective competition in the market is ensured by the "as efficient" competitors, i.e. hypothetical competitors, which have the same costs as the dominant company. ${ }^{22}$ As mentioned, there is no intention to protect all the competitors and for the Commission it is acceptable that the competitors, who deliver less to the consumers in terms of price, choice, quality and innovation, will leave the market. ${ }^{23}$ Although the Commission pays huge attention to the consumers' protection, it does not explain how to determine whether consumers experience loses or not when competitors are excluded from the market. We believe that probably the Commission relies on the presumption that actions of the dominant undertaking, which help to eliminate "as efficient" competitors cause damage to the competition and this also causes damage to the consumers.

While analysing the decisions of the Commission, it is not clear whether the Commission intends to determine real effect of the actions of the undertakings for the consumers and the market. Former head of the Directorate General for Competition P. Lowe has noted that it is quite difficult to determine the effect to the market, which has been caused by the dominant undertakings. Therefore, according to P. Lowe, in cases related to application of the Article 102 of the TFEU, it is necessary to rely on formal criteria. ${ }^{24}$ Position of $\mathrm{P}$. Lowe does not correspond to the official aspiration of the Commission to pay main attention to the evaluation of the effect, which has been caused by the dominant undertakings to the consumers and the market. ${ }^{25}$

20 Commission of the European Communities. Communication from the Commission. Guidance on the Commission's Enforcement Priorities in Applying Article 82 of the EC Treaty to Abusive Exclusionary Conduct by Dominant Undertakings. (2009/C 45/02), para. 5.

21 Ibid., para. 19.

22 European Commission, DG Competition. Discussion Paper on the Application of Article 82 of the Treaty to Exclusionary Abuses. Brussels, December, 2005 [interactive]. [accessed on 11-7-2007]. <http:// ec.europa.eu/comm/ competition/antitrust/art82/discpaper2005.pdf>, para. 63.

23 Commission of the European Communities. Communication from the Commission. Guidance on the Commission's Enforcement Priorities in Applying Article 82 of the EC Treaty to Abusive Exclusionary Conduct by Dominant Undertakings. (2009/C 45/02), para. 6.

24 Lowe, P. Director General, EC Commission Directorate-General for Competition. Consumer Welfare and Efficiency - New Guiding Principles of Competition Policy?. 13th International Conference on Competition and 14th European Competition Day. Munich: 27th March 2007.

25 Kroes, N. European Commissioner for Competition Policy. Preliminary Thoughts on Policy Review of Article 82. Speech at the Fordham Corporate Law Institute. New York: 23rd September 2005. 
In the practice of the Court of Justice and the General Court, there is also a lack of consistency. During the analysis of the Article 101 of the TFEU in Österreichische Postsparkasse AG and GlaxoSmithKline cases, the General Court proclaimed welfare of the consumers as the main goal of the competition law. ${ }^{26}$ Moreover, President of the General Court stated in paragraph 145 of the IMS Health Inc. case that Commission gratuitously established a link between effective competition and the interests of the particular competitors. The President of the General Court believed that primary purpose of the Article 102 of the TFEU is to prevent the distortion of competition, and, especially, to safeguard the interests of consumers rather than to protect the position of particular competitors. ${ }^{27}$ However, during appeal proceedings the President of the Court of Justice stated that the reasoning of the General Court provided in paragraph 145 cannot be accepted without reservation, i.e. it should not be understood as excluding competition from the aim pursued by the Article 102 of the TFEU. The President of the Court of Justice believed that interests of competitors cannot be separated from the maintenance of an effective competition structure. ${ }^{28}$ Therefore, although the General Court recognized protection of the consumers as the main aim of the Article 102 of the TFEU, the Court of Justice emphasized protection of the interests of the competitors in the appeal decision.

The Court of Justice in Continental Can and British Airways cases stated that the Article 102 of the TFEU is intended to prohibit not only actions of the dominant undertakings, which cause prejudice to consumers directly, but also such actions, which cause damage to the consumers through negative impact on an effective competition structure. ${ }^{29}$ In France Telecom case the General Court dismissed argument made by Wanadoo Company that pricing policy of Wanadoo have not caused any damage to consumers and even was beneficial to them. The Court of Justice claimed that the competition law aims to protect structure of the market from false distortions because in such case interests of the consumers are safeguarded in a best way. Moreover, according to the Court, it is not necessary to prove that certain behaviour has a direct negative effect on the consumers. ${ }^{30}$

Analysis of the practice of the Court of Justice and the Commission does not allow identifying clearly the one main, dominating goal of the competition law. In most cases,

26 Joined cases T-231/01 and T-214/01 Österreichische Postsparkasse AG and Bank für Arbeit und Wirtschaft AG v. Commission of the European Communities [2006], para. 115; Case T-168/01 GlaxoSmithKline Services Unlimited v. Commission of the European Communities [2006], para. 171.

27 Order of the President of the Court of First Instance T-184/01 R, IMS Health Inc., v. Commission of the European Communities [2001], para. 145.

28 Order of the President of the Court C-481/01 NDC Health GmbH \& Co KG and NDC Health Corporation v. Commission of the European Communities [2002], para. 84.

29 Decision of the Court of Justice in C-95/04 P British Airways v. plc Commission of the European Communities [2007], para. 106; Decision of the Court of Justice in C-6/72 Europemballage Corpn and Continental Can v. Commission of the European Communities [1973], para. 26.

30 Decision of the General Court case T-340/03 France Télécom SA v. Commission of the European Communities, para. 266; Decision of the General Court case T-219/99, British Airways plc v. Commission of the European Communities, para. 264. 
courts mention goals such as protection of the effective competition, protection of the competitors and protection of the consumers. Generally, the Court of Justice and the EU Commission aim to decide whether dominant undertakings cause any damage to competition and competitors and not to the consumers. Authors of this article believe that the Court of Justice and the Commission should evaluate possible influence to consumers and not the fact how respective actions of the dominant undertaking could have affected its competitors in order to decide whether dominant undertaking have caused any damage to "effective competition structure". Only actions, which have caused damage to consumers, should be recognized as detrimental to "effective competition structure". In case actions of the dominant undertaking have not caused damage to the consumers, then, despite effect on the competitors, structure of the market also should not be taken as damaged. ${ }^{31}$ Moreover, the Court of Justice and the Commission should formulate consistent position how damage caused to the consumers is going to be established.

From the practical point of view, in the competition law it is important to evaluate economic effect of the actions of the undertakings and possible negative effect on consumers. Not paying enough attention to these factors may result in controversial decisions of competition institutions and the courts. In application of the Article 102 of the TFEU cases related to predatory pricing ${ }^{32}$ and rebates ${ }^{33}$ are clear examples of controversial decisions. In predatory pricing case damage to the consumers will be made only if the undertaking is capable to recoup losses. Without actual recoupment of losses taking place, damage may be caused only to competitors. Consequently, if protection of the consumers is recognized as the main goal of the competition law, then recoupment of losses should be recognized as a necessary constituent element of predatory pricing. Therefore, the predatory pricing should be viewed as illegal only in case it is possible to prove recoupment of losses.

At the same time, we should bear in mind that Article 102 of the TFEU is not a part of the consumers' protection law; therefore, in order to establish breach of this article, it is also necessary to establish restriction of the competition when legality of exclusionary abuse is assessed. ${ }^{34}$ Therefore, in these cases, competition institutions should prove that

31 Such position is supported by a number of legal scholars - O'Donoghue, R. and Padilla, A. J. The Law and Economics of Article 82 EC. Oxford: Hart Publishing, 2006, para. 221; Vickers, J. Abuse of Market Power. Speech to the 31st Conference of the European Association of Research in Industrial Economics, Berlin: September 3rd, 2004; Evans, D.; Chang, H. and Schmalensee R. Has the Consumer Harm Standard Lost Its Teeth? in Hahn R.,W. (ed.), High-Stakes Antitrust: The Last Hurrah? Washington DC: Brookings Institution, 2003, pp. 72 et seq; EAGCP. An economic approach to Article 82. July, 2005 [interactive]. [accessed on 30-6-2006]. <http://ec.europa.eu/comm/competition/publications/ studies/ eagcp_july_21_05.pdf>.

32 Moisejevas, R. Recoupment of Losses by the Dominant Undertaking, Which Has Allegedly Engaged in Predatory Pricing. Legality of Actions. Jurisprudencija. 2010, 2(120).

33 Cseres, K.J. The Controversies of the Consumer Welfare Standard. The Competition Law Review. 2007, 3(2): 147.

34 Case T-203/01 Michelin v. Commission of the European Communities [2003], para. 237; Case T-201/04 Microsoft Corp v. Commission of the European Communities [2007], para. 867. 
damage to the consumers has been caused by the illegal restriction of the competition. ${ }^{35}$ Of course, undertakings conclude an agreement which is recognized as it is not necessary to prove the fact of the damage to the consumers.

\section{The interpretation of the "consumer" concept under competition law}

As a rule, the concept of "consumer" is defined differently in consumer and competition laws. EU legal acts provide that consumers are natural persons, which act for purposes outside their trade, business, craft or profession. ${ }^{36}$ The Law on Protection on Consumer Rights of the Republic of Lithuania in the Article 2 (15) similarly provides that "consumer" means a natural person, who expresses his intention to buy, buys and uses goods or services to meet his own personal, family or household needs, which are outside his business or profession.

On the other hand, in the sphere of the competition law, the Commission in the notice "Guidelines on the Application of Article 81(3) of the Treaty" provided that "the concept of 'consumers' encompasses all direct or indirect users of the products covered by the agreement, including producers that use the products as an input, wholesalers, retailers and final consumers, i.e. natural persons who are acting for purposes which can be regarded as outside their trade or profession. In other words, consumers within the meaning of Article 81(3) are the customers of the parties to the agreement and subsequent purchasers. These customers can be undertakings as in the case of buyers of industrial machinery or an input for further processing or final consumers as for instance in the case of buyers of impulse ice-cream or bicycles. " ${ }^{37}$ It was mentioned that the EC Merger Regulation also mentions the intermediate and ultimate consumers. ${ }^{38}$

Therefore, the competition law defines the concept of "consumers" much broader than this concept is used in consumer protection law. Under the competition law, concept of "consumers" does not refer exclusively or only to protection of final consumers (natural persons). The competition law is basically focused on economic interests of

35 Akman, P. Consumer Welfare and Article 82EC: Practice and Rhetoric. ESRC Centre for Competition Policy and Norwich Law School, University of East Anglia. CCP Working Paper 08-25, (2009) 32 World Competition, p. 23.

36 Directive 1999/44/EC of the European Parliament and of the Council of 25 May 1999 on Certain Aspects of the Sale of Consumer Goods and Associated Guarantees, OJ 1999, L 171, Art. 1(2)(a); Directive 2002/65/EC of the European Parliament and of the Council of 23 September 2002 Concerning the Distance Marketing of Consumer Financial Services and Amending Council Directive 90/619/EEC and Directives 97/7/EC and 98/27/EC, OJ 2002, L 271/16, Art. 2 (d); Directive 2005/29/EC of the European Parliament and of the Council of 11 May 2005 Concerning Unfair Business-to-Consumer Commercial Practices in the Internal Market and Amending Council Directive 84/450/EEC, Directives 97/7/EC, 98/27/ EC and 2002/65/EC of the European Parliament and of the Council and Regulation (EC) No 2006/2004 of the European Parliament and of the Council, OJ 2005, L 149/22, Art. 2 (a).

37 Communication from the Commission Notice Guidelines on the Application of Article 81 (3) of the Treaty, OJ 2004, C 101/97.

38 Regulation (EC) 139/2004 on the Control of the Concentrations Between Undertakings, OJ 2004, L 24/1. 
consumer, whereas laws on consumer protection aim to protect much broader interests of consumers, such as right to receive information, health and security. ${ }^{39}$ Cseres notes that definition of "consumers" provided by the Commission in notice "Guidelines on the Application of Article 81(3) of the Treaty" promotes intermediate buyers to 'honorary' consumers. Moreover, usually it is evaluated what effect a unilateral behaviour or anticompetitive agreement will have on intermediate buyers and not on final consumers. In most cases, the Commission and national competition authorities believe that harm to intermediate buyers will cause damage to final consumers. ${ }^{40}$

However, there are several cases when the General Court in competition cases referred directly to final consumers. In Österreichische Postsparkasse $A G$ case, the General Court claimed that "the ultimate purpose of the rules that seek to ensure that competition is not distorted in the internal market is to increase the well-being of consumers (...) competition law and competition policy therefore have an undeniable impact on the specific economic interests of final customers who purchase goods or services." 41 In GlaxoSmithKline case, the General Court claimed that "in effect, the objective assigned to Article 81(1) EC, which constitutes a fundamental provision indispensable for the achievement of the missions entrusted to the Community, in particular for the functioning of the internal market (...), is to prevent undertakings, by restricting competition between themselves or with third parties, from reducing the welfare of the final consumer of the products in question (...). At the hearing, in fact, the Commission emphasised on a number of occasions that it was from that perspective that it had carried out its examination in the present case, initially concluding that the General Sales Conditions clearly restricted the welfare of consumers, then considering whether that restriction would be offset by increased efficiency which would itself benefit consumers. " 42

\section{Some ideas on the Priorities of the Lithuanian Competition Council}

Article 46 (4) of the Constitution of the Republic of Lithuania specifies that the law shall prohibit monopolisation of production and the market and shall protect freedom of fair competition. Practically, in the same manner Article 1(1) of the Lithuanian Law on Competition provides that the purpose of this law is to protect freedom of fair competition in the Republic of Lithuania. In order to provide more details concerning

39 Cseres, K.J. The Controversies of the Consumer Welfare Standard. The Competition Law Review. 2007, 3(2): 170 .

40 Cseres, K.J. The Controversies of the Consumer Welfare Standard. The Competition Law Review. 2007, 3(2): 131-132.

41 Joined cases T-231/01 and T-214/01 Österreichische Postsparkasse AG and Bank für Arbeit und Wirtschaft AG v. v. Commission of the European Communities [2006], para. 115.

42 Case T-168/01 GlaxoSmithKline Services Unlimited v. Commission of the European Communities [2006], para. 171. 
enforcement priorities (and, therefore, also objectives of the competition law), the Lithuanian Competition Council on the 2nd of July, 2012 adopted resolution No. 1S89 "Concerning Priority of the Activities of the Lithuanian Competition Council" (hereinafter - Resolution on Priority). ${ }^{43}$ Respective resolution of the Lithuanian Competition Council establishes main guiding principles for the Council in its decision making in cases of initiation of the relevant investigation of alleged infringement of the Law on Competition. However, it is also stated that the Council has a right to refer to them in other cases when it is implementing its other functions related to implementation of competition policy in Lithuania. The authors believe that the establishment of main guiding principles may have important practical consequences to the everyday activities of the Lithuanian competition authority, especially if the Competition Council uses its right when taking its decisions on infringements of provisions of the Law on Competition. Resolution on Priority stipulates that the Lithuanian Competition Council aims to perform investigations or otherwise interfere to the market operation, if such interference may substantially add to the protection of the effective competition and ensure better consumer welfare in this way. Therefore, the Lithuanian Competition Council proclaimed that effective competition and consumer welfare are the two main goals that should be achieved. Such goals correspond to the objectives established under the European Union law. Furthermore, the Lithuanian Competition Council noted that usually the most negative effect on the effective competition and consumer welfare is caused by the following actions:

1) Those, which directly affect prices of goods, their quality and variety;

2) Those, which directly limit the possibility of the undertakings to act in the relevant market by closing or partitioning of the market or through expulsion from the market;

3) Those, which directly affect the relevant part of the undertakings or consumers operating in Lithuania;

4) Those, which are directly related with goods intended for consumers. ${ }^{44}$

Some of the above mentioned examples directly refer to the actions of the undertakings that may affect the welfare of consumers, e.g., actions of the undertakings which directly affect prices of goods, their quality and also actions that are directly related with goods intended for consumers. On the other hand, some of the outlined examples refer to the actions of the undertakings that may affect the welfare of the competitors, e.g., actions of the undertakings, which limit possibility of the undertakings to act in the relevant market, and actions, which directly affect the relevant part of the undertakings (competitors) operating in Lithuania. Therefore, from analysis of the Resolution on Priority, it follows that the Lithuanian Competition Council actually sees priority of its actions not only as a protection of effective competition and consumers, but also seeks to protect competitors.

43 Lietuvos Respublikos Konkurencijos tarybos nutarimas dẻl Lietuvos Respublikos Konkurencijos tarybos veiklos prioriteto, $2012 \mathrm{~m}$. liepos 2 d. Nr. 1S-89, Vilnius. 
Moreover, the Resolution on Priority provides that most of direct or indirect damage to consumers is produced, if respective illegal actions cause increase of prices, supply of goods is diminished or the level of goods innovations is lowered..$^{45}$

It is important to note that the Lithuanian Competition Council has a right to decide on the basis of the Resolution on Priority whether to start investigation into actions of the undertakings or not. The Lithuanian Law on Competition provides that the Lithuanian Competition Council shall refuse starting the investigation, if the examination of the factual circumstances described in the application does not correspond to the guiding principles established in the Resolution on Priority. We may conclude that the Resolution on Priority expands discretion of the Lithuanian Competition Council to choose which investigations to start and which refuse starting and indicates its main enforcement priorities.

\section{Conclusions}

1. There are multiple objectives in competition law: the integration of the Internal Market, the protection of consumers, protection of the competitors, freedom of competition, economic efficiency, etc. The Court of Justice, the EU Commission and national competition institutions in decision making process usually take into consideration a number of competition law goals.

2. Enforcement of competition law should focus on economic assessment of the actions of the undertaking concerned and evaluation whether actions under consideration cause damage to the consumers or not. Protection of the interest of the consumers should be given priority in relation to the protection of the competitors and should be implemented in line with the goal of protection of competitive process and effective competition as such. On the other hand, protection of the interests of competitors does not necessarily increase welfare of consumers. Moreover, the Court of Justice and the Commission should formulate consistent position how damage caused to the consumers is going to be established and clearly establish the rule which goal shall be dominant in the enforcement of the EU competition law.

3. It should be noted that the competition law defines the concept of "consumers" much broader than this concept is used in consumer protection law and thus it seeks to protect the interests of all consumers (including undertakings), not only limiting to the interests of final consumers (natural persons). The competition law is basically focused with economic interests of consumers, whereas laws on consumer protection aim to protect much broader interest of (but only final) consumers, such as the right to receive information, health and security.

4. The Lithuanian Competition Council on the $2^{\text {nd }}$ of July, 2012 adopted resolution establishing priority of the activities of the Lithuanian Competition Council which stipulates Lithuanian Competition Council's aims in performance of investigations or

45 Lietuvos Respublikos Konkurencijos tarybos nutarimas dèl Lietuvos Respublikos Konkurencijos tarybos veiklos prioriteto, $2012 \mathrm{~m}$. liepos $2 \mathrm{~d}$. Nr. 1S-89, Vilnius. 
otherwise interference to the market operation and emphasises that such aims are of special priority, if the Council's interference may substantially add to the protection of the effective competition and thus ensure better consumer welfare. The Lithuanian Competition Council has a right to decide on priority whether to start investigation into actions of the undertakings on the basis of the respective Resolution and may refer to its designated priorities also in other cases of enforcement of competition law, so the mentioned resolution may have important practical consequences in the everyday activities of the Lithuanian national competition authority.

\section{References}

Akman, P. Consumer Welfare and Article 82EC: Practice and Rhetoric, ESRC Centre for Competition Policy and Norwich Law School, University of East Anglia. CCP Working Paper 08-25, (2009) 32 World Competition.

Antitrust: Consumer Welfare at Heart of Commission Fight Against Abuses by Dominant Undertakings. Brussels: 3rd December 2008, IP/08/1877.

Case C-6/72 Europemballage Corpn and Continental Can v. Commission of the European Communities [1973].

Case C-49/92 P, Anic Partecipazioni, [1991] ECR I-4125.

Case C-126/97 Eco Swiss [1999] ECR I-3055.

Case C-453/99 Courage v. Crehan [2001] ECR I-627.

Case T-219/99, British Airways plc v. Commission of the European Communities.

Case T-168/01 GlaxoSmithKline Services Unlimited v. Commission of the European Communities [2006].

Case T-203/01 Michelin v. Commission of the European Communities [2003].

Case T-340/03 France Télécom SA v. Commission of the European Communities.

Case C-95/04 P British Airways v. plc Commission of the European Communities [2007].

Case T-201/04 Microsoft Corp v. Commission of the European Communities [2007].
Commission of the European Communities. Communication from the Commission. Guidance on the Commission's Enforcement Priorities in Applying Article 82 of the EC Treaty to Abusive Exclusionary Conduct by Dominant Undertakings. (2009/C 45/02).

Communication from the Commission Notice Guidelines on the Application of Article 81 (3) of the Treaty, OJ 2004, C 101/97.

Cseres, K.J. The Controversies of the Consumer Welfare Standard. The Competition Law Review. 2007, 3(2).

Directive 1999/44/EC of the European Parliament and of the Council of 25 May 1999 on Certain Aspects of the Sale of Consumer Goods and Associated Guarantees, OJ 1999, L 171.

Directive 2002/65/EC of the European Parliament and of the Council of 23 September 2002 Concerning the Distance Marketing of Consumer Financial Services and Amending Council Directive 90/619/ EEC and Directives 97/7/EC and 98/27/EC, OJ 2002, L 271/16.

Directive 2005/29/EC of the European Parliament and of the Council of 11 May 2005 Concerning Unfair Business-toConsumer Commercial Practices in the Internal Market and Amending Council Directive 84/450/EEC, Directives 97/7/ EC, $98 / 27 / E C$ and $2002 / 65 / E C$ of the European Parliament and of the Council and Regulation (EC) No 2006/2004 of the 
European Parliament and of the Council, OJ 2005, L 149/22.

European Commission, DG Competition. Discussion Paper on the Application of Article 82 of the Treaty to Exclusionary Abuses. Brussels, December 2005 [interactive]. [accessed on 11-7-2007]. $<$ http://ec.europa.eu/comm/ competition/ antitrust/art82/discpaper2005.pdf $>$.

Evans, D.; Chang, H. and Schmalensee R. Has the Consumer Harm Standard Lost Its Teeth? in Hahn R., W. (ed.), High-Stakes Antitrust: The Last Hurrah? Washington DC: Brookings Institution, 2003.

The Unilateral Conduct Working Group. International Competition Network. Report on the Objectives of Unilateral Conduct Laws, Assesment of Dominance/ Substantial Market Power, and State Created Monopolies. 2013, p. 6 [interactive]. [accessed on 21-5-2013]. <http://www. internationalcompetitionnetwork.org/ uploads/library/doc353.pdf>.

Gormsen, L.L. Article 82 EC: Where Are We Coming From and Where Are We Going to? The Competition Law Review. 2006, 2(2).

Lianos, I. Some Reflections on the Question of the Goals of EU Competition Law, Centre for Law, Economics and Society. CLES Working Paper Series. 2013(3).

Joined cases T-231/01 and T-214/01 Österreichische Postsparkasse AG and Bank für Arbeit und Wirtschaft AG v. Commission of the European Communities [2006].

Kroes, N. European Commissioner for Competition Policy. Preliminary Thoughts on Policy Review of Article 82. Speech at the Fordham Corporate Law Institute. New York: 23rd September 2005.

Law on Competition of the Republic of Lithuania. Official Gazette. 1999, No. 30-
856. (new edition from 01/05/2012. 2012, Nr. 42-2041).

Lietuvos Respublikos Konkurencijos Tarybos Nutarimas dèl Lietuvos Respublikos Konkurencijos Tarybos Veiklos Prioriteto, 2012 m. liepos 2 d. Nr. 1S-89, Vilnius.

Lowe, P. Director General, EC Commission Directorate-General for Competition. Consumer Welfare and Efficiency New Guiding Principles of Competition Policy? 13th International Conference on Competition and 14th European Competition Day. Munich: 27th March 2007.

Order of the President of the Court of First Instance T-184/01 R, IMS Health Inc., v. Commission of the European Communities [2001].

Order of the President of the Court C-481/01 NDC Health GmbH \& Co KG and NDC Health Corporation v. Commission of the European Communities [2002].

O'Donoghue, R. and Padilla A. J. The Law and Economics of Article 82 EC. Oxford: Hart Publishing, 2006.

Regulation (EC) 139/2004 on the Control of the Concentrations Between Undertakings, OJ 2004, L 24/1.

EAGCP. An Economic Approach to Article 82. July, 2005 [interactive]. [accessed on 30-6-2006]. <http://ec.europa.eu/comm/ competition/publications/studies/eagcp july_21_05.pdf $>$.

Vickers, J. Abuse of Market Power. Speech to the 31 st Conference of the European Association of Research in Industrial Economics. Berlin: September 3rd, 2004.

Wesseling, R. The Modernisation of EC Antitrust Law. Oxford: Hart Publishing, 2000.

Whish, R.; Bailey, D. Competition Law. Seventh Edition. London: Oxford University Press, 2012. 


\title{
KAI KURIOS PASTABOS DĖL PAGRINDINIŲ ES KONKURENCIJOS TEISĖS TIKSLŲ
}

\author{
Raimundas Moisejevas, Ana Novosad \\ Mykolo Romerio universitetas, Lietuva
}

Santrauka. ES Komisijos ir Teisingumo Teismo praktikoje yra išskiriama daug konkurencijos teisés tikslu. Dažniausiai nurodomi šie konkurencijos teises tikslai: vienos rinkos integracija, vartotoju apsauga, konkurentu apsauga, konkurencijos laisve, ekonominis efektyvumas. Straipsnyje analizuojami ịvairüs konkurencijos teisès tikslai ir aptariamas šiu tikslu. tarpusavio ryšys. Ypatingas demesys yra skiriamas vartotoju apsaugai kaip vienam pagrindiniu konkurencijos teises tikslų. Aptariant vartotoju apsaugos tiksla taip pat paaiškinamas skirtumas tarp vartotojo savokos skirtumu konkurencijos ir vartotoju teisiu srityse. Autoriai iš dalies kritiškai ivvertina Europos Komisijos ir Teisingumo Teismo praktika, kurioje trüksta nuoseklumo vertinant vartotoju interesu apsauga kitu konkurencijos teises tikslu kontekste. Šio straipsnio aktualuma sustiprina aplinkybe, kad Lietuvos Respublikos konkurencijos taryba 2012 metais prieme nutarima „Dél Lietuvos Respublikos konkurencijos tarybos veiklos prioriteto", kuriame itvirtino pagrindinius principus, taikomus igyvendinant konkurencijos politika Lietuvoje. Pagrindiniu konkurencijos teises tikslu nustatymas minètame Lietuvos konkurencijos tarybos dokumente gali turèti svarbias praktines pasekmes kasdieneje nacionalines Konkurencijos tarybos veikloje. Be to, šis dokumentas apibendrina atitinkama Lietuvos konkurencijos tarybos praktika. Siame straipsnyje siekiama aptarti skirtingus Lietuvoje ir ES nustatytus konkurencijos teisés tikslus.

Reikšminiai žodžiai: konkurencijos teises tikslai, piktnaudžiavimas dominuojančia padetimi, antikonkurenciniai susitarimai, vidaus rinkos integracija, vartotoju apsauga, efektyvi konkurencija.

Raimundas Moisejevas, Mykolo Romerio universiteto Teisès fakulteto Verslo teisès katedros docentas, socialinių mokslų daktaras. Mokslinių tyrimų kryptys: konkurencijos teisè, ES teisè, komercinè teisè, įmonių teisè.

Raimundas Moisejevas, Mykolas Romeris University, Faculty of Law, Business Law Department, Associated Professor, Doctor of Law. Research interests: EU competition law, EU law, commercial law, corporate law.

Ana Novosad, Mykolo Romerio universiteto Teisės fakulteto Verslo teisès katedros lektorè, socialinių mokslų daktarè. Mokslinių tyrimų kryptys: konkurencijos teisè, komercinè teisè, sutarčių teisè.

Ana Novosad, Mykolas Romeris University, Faculty of Law, Department of Business Law, lecturer, Doctor of Law. Research interests: competition law, commercial law, contract law. 